\title{
Temperature requirements of Scytosiphon Iomentaria (Scytosiphonales, Phaeophyta) from the Gulf of Thessaloniki, Greece, in relation to geographic distribution
}

\author{
S. Orfanidis*, S. Haritonidis \& I. Tsekos \\ Botanical Institute, Department of Biology, University of Thessaloniki; \\ 54006 Thessaloniki, Greece
}

\begin{abstract}
Temperature requirements for growth, reproduction and formation of macrothalli of a day-neutral strain of Scytosiphon lomentaria from the Gulf of Thessaloniki were experimentally determined and correlated with the geographic distribution in the North Atlantic Ocean. The microthallus grew in a wider temperature interval and better at higher temperatures than did the macrothallus. Germlings acclimated to 5 or $15^{\circ} \mathrm{C}$ grew sufficiently $(>20 \%$ of maximum rate) and developed into macrothalli at $5-25^{\circ} \mathrm{C}$ and $5-27^{\circ} \mathrm{C}$. Macrothalli acclimated to 10 or $15^{\circ} \mathrm{C}$ grew sufficiently at $5-20^{\circ} \mathrm{C}$. Macrothalli acclimated to $15^{\circ} \mathrm{C}$ survived at $-1{ }^{\circ} \mathrm{C}$ and reproduced at 5 to $23^{\circ} \mathrm{C}$. Regardless of the acclimation temperature, germlings and macrothalli grew optimally $(>80 \%$ of maximum rate) at $15-25^{\circ} \mathrm{C}$ and at $10-15^{\circ} \mathrm{C}$. The experimental data explain only the southern distribution boundary of Scytosiphon in the North Atlantic. This boundary is composite in nature: on the European coasts it is a growth boundary, whereas on the American coasts it is a lethal one.
\end{abstract}

\section{INTRODUCTION}

Scytosiphon lomentaria (Lyngbye) Link is a species widely distributed in the eulittoral and upper sublittoral zone of temperate coasts. Typically, it has a heteromorphic life-cycle with a crustose microthallus, and an upright tube-like macrothallus. The macrothallus can be either constricted (cylindrical type) or flattened and non-constricted (complanate type). Strains have been reported with plurispores that directly replicate the mother plants (Kristiansen \& Pedersen, 1979; Kristiansen et al., 1991). Formation of the macrothallus from the crust is either a short-day photoperiodic reaction or a day-neutral reaction. Both take place within a definite temperature range (Correa et al., 1986). Temperatures $>20^{\circ} \mathrm{C}$ usually inhibit macrothallus formation, irrespective of daylength (Lüning, 1980; tom Dieck, 1987).

It is generally accepted that both temperature and photoperiod constitute the most important factors that determine the geographic distribution of seaweed (Breeman, 1988; Lüning, 1990). The wide geographic distribution of Scytosiphon lomentaria is explained by its survival temperatures under laboratory conditions ( 0 to $27 / 28^{\circ} \mathrm{C}_{\text {; }}$ tom Dieck, 1987 ).

\footnotetext{
- Present address of first author: Centre for Marine Biology, University of Groningen, Biological Centre, P.O. Box 14, 9750 AA Haren (Gn), The Netherlands
} 
The types of geographic boundaries existing in the North Atlantic have mainly been discussed on the basis of temperature requirements for the formation of macrothalli (van den Hoek, 1982). The temperature range for the formation of macrothalli differs among strains from the same geographic latitude (cf. Lüning, 1980; Pedersen, 1980; Correa et al., 1986; Pedersen et al., 1987) or even between strains coming from adjacent areas (Kristiansen et al., 1991). The first objective of the present paper was to determine the temperature responses of $S$. lomentaria from Thessaloniki and to correlate these responses with its geographical distribution in the North Atlantic Ocean.

According to Precht et al. (1973), non-genetic adaptation [or acclimation sensu Berry \& Björkman (1980)] occurs more often in eurythermal marine animals than in stenothermal ones. The ability of marine algae to change their thermal requirements and the limits of their survival in respect to cultivation temperature has not been completely investigated (Schwenke, 1959; Lutova \& Feldmann, 1960; Feldmann \& Lutova, 1963; Yarish et al., 1987; Bischoff \& Wiencke, 1993; Orfanidis \& Haritonidis, 1994). The second objective of this study was to determine whether Scytosiphon from Thessaloniki was able to change its growth behaviour or temperature requirements for the formation of macrothalli according to precultivation temperature.

\section{MATERIAL AND METHODS}

\section{Unialgal cultures}

Clonal unialgal cultures of Scytosiphon lomentaria were established from plurispores isolated from macrothalli that were collected in February 1986 near Thessaloniki, Greece (Thermaikos Gulf; $40.38^{\circ} \mathrm{N}, 22.58^{\circ} \mathrm{E}$ ). Cultures were transported in insulated cooling containers to a laboratory at the Biologische Anstalt Helgoland in Hamburg. The standard cultivation temperature used was $15 \pm 2{ }^{\circ} \mathrm{C}$. Cultivation methods and equipment used in this study were described in detail by Orfanidis (1991).

\section{Relative growth rates}

Growth experiments were performed in temperature-controlled water baths (Haake D8-V, Karlsruhe, Germany; $\pm 0.2^{\circ} \mathrm{C}$ ) at $0,5,10,15,20,25^{\circ} \mathrm{C}$ and $27^{\circ} \mathrm{C}$. The photon fluence rate at the surface of the water baths was $60-80 \mu \mathrm{mol} \mathrm{m}{ }^{-2} \mathrm{~s}^{-1}$ (Osram L $65 \mathrm{~W} / 25 \mathrm{~S}$ and Osram L $40 \mathrm{~W} / 25 \mathrm{~S}$ ). The day length was $16 \mathrm{~h}$ of light per day. Temperaturedependent growth rates of Scytosiphon lomentaria under light-saturated conditions (Orfanidis, 1992) were estimated either for germlings or macrothalli. The material which was used for the experiments had been either pre-incubated for at least 2 years at $15^{\circ} \mathrm{C}$ or for 1 month at 5 or $10^{\circ} \mathrm{C}$. The zoids of $S$. lomentaria that were released from macrothalli were allowed to settle on glass slides for $3-5 \mathrm{~h}$, and then put into $50-\mathrm{ml}$ Erlenmeyer flasks. One-cell germlings were also exposed to the experimental temperatures. Growth was determined by counting the number of cells $(n=20-30)$ at the end of the experiment. In a preliminary experiment, it was found that the formation of macrothalli had begun during the first week of cultivation at $20^{\circ} \mathrm{C}$. The experimental time of the above experiment was 5 days at temperatures from 15 to $27^{\circ} \mathrm{C}$ and 7 days at temperatures from 0 to $10^{\circ} \mathrm{C}$. Apical fragments of macrothalli of equal length were cultivated over a period of 7 days at each temperature and used for estimation of macrothallus growth. 
The relative growth rate (RGR) was calculated as follows:

$$
\mathrm{RGR}=\left(\ln \mathrm{N}_{\mathrm{t}}-\ln \mathrm{N}_{\mathrm{o}}\right) / \mathrm{t} \times 7\left(\mathrm{week}^{-1}\right)
$$

$\left[N_{0}=\right.$ number of cells or initial length; $N_{t}=$ number of cells or length after $t$ days; $t=$ experimental time (days)]

Relative growth rates that exceeded $20 \%$ and $80 \%$ of the maximum value were defined as "sufficient" growth or "optimum" growth, respectively.

\section{Reproduction and formation of macrothalli at different temperatures}

Experiments on reproduction were performed in six different culture rooms $(0,5,10$, $15^{\circ} \mathrm{C} \pm 2{ }^{\circ} \mathrm{C}$ and $20,25^{\circ} \mathrm{C} \pm 1{ }^{\circ} \mathrm{C}$ ) with material pre-incubated for at least 2 years at $15^{\circ} \mathrm{C}$. A photon fluence rate of $30-35 \mu \mathrm{mol} \mathrm{m} \mathrm{m}^{-2} \mathrm{~s}^{-1}$ was provided by cool-white fluorescent tubes (Osram L $40 \mathrm{~W} / 25 \mathrm{~S}$ ) for $16 \mathrm{~h}$ per day. Zoids released from macrothalli were allowed to settle in crystallizing dishes $(90 \mathrm{~mm}$ in diameter), and were then transferred to the experimental temperatures. The medium was changed weekly from 15 to $25^{\circ} \mathrm{C}$ and every second week from 0 to $10^{\circ} \mathrm{C}$. The plants were examined microscopically, and the presence or absence of sporangia was noted. For a more precise determination of reproduction at higher temperatures $\left(22,23,24\right.$ and $\left.25^{\circ} \mathrm{C} \pm 0.2^{\circ} \mathrm{C}\right)$, immature macrothalli were incubated in temperature-controlled water baths as described above. The temperature-dependent formation of macrothalli in material pre-incubated for at least 2 years at $15^{\circ} \mathrm{C}$ and then for 1 month at $5^{\circ} \mathrm{C}$ was examined in the same system. The proportion of zoids that developed into macrothalli was quantitatively determined.

\section{RESULTS}

Macrothalli of Scytosiphon lomentaria that were pre-incubated at $10^{\circ} \mathrm{C}$ for one month, or at $15^{\circ} \mathrm{C}$ for at least two years, grew optimally at $10-15^{\circ} \mathrm{C}$ and sufficiently at $5-20^{\circ} \mathrm{C}$ (Fig. 1A). Germlings that were pre-incubated at $5^{\circ} \mathrm{C}$ for one month, or at $15^{\circ} \mathrm{C}$ for at least two years, grew better at higher temperatures, with optimum growth at $15-25^{\circ} \mathrm{C}$ and sufficient growth at $5-25^{\circ} \mathrm{C}$. At $27^{\circ} \mathrm{C}$, only the germlings released from plants preincubated at $15^{\circ} \mathrm{C}$ grew measurable (Fig. 1B). The macrothalli survived a temperature of $-1^{\circ} \mathrm{C}$ for eight weeks.

Zoids released from the plurilocular sporangia of macrothalli became rounded (embryospores) after 2-5 h. Germination was unipolar (type A, sensu Pedersen, 1981) and independent of temperature. Following germination, a multi-celled prostrate system developed bearing hairs. Later, one or more uniseriate filaments evolved into parenchymatic macrothalli.

Reproduction of macrothalli at different temperatures, under long-day conditions, exhibited the following pattern: Two weeks after the release of zoids, i.e. at the initiation of the experiment, sterile macrothalli were observed at 15,20 and $25^{\circ} \mathrm{C}$. Mature plurilocular sporangia were observed in the macrothalli, and an extensive release of zoids was detected at 15 and $20^{\circ} \mathrm{C}$ in the following two weeks. No zoids were released at $25^{\circ} \mathrm{C}$ after 12 weeks. The dark brown to black macrothalli remained small, and very easily became detached when the nutrient solution was renewed. At $10^{\circ} \mathrm{C}$, the first macrothalli appeared after two weeks; then, two weeks later, macrothallus formation was completed. 

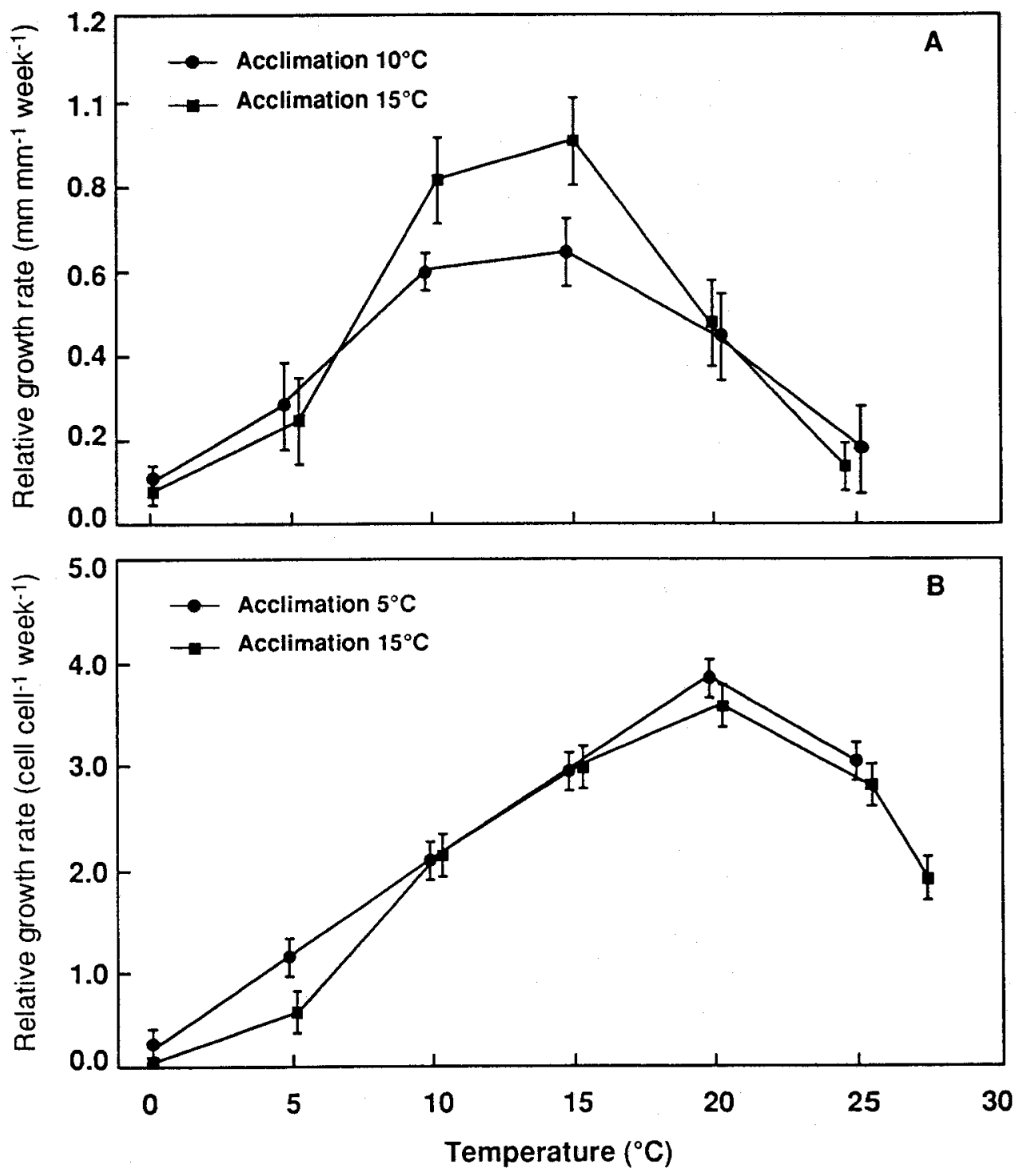

Fig. 1. A: Mean relative growth rates (RGR) of macrothalli of Scytosiphon lomentaria $(\mathrm{n}=8)$ acclimated for one month to $10^{\circ} \mathrm{C}$ or for at least two years to $15^{\circ} \mathrm{C}$. B: Mean relative growth rates (RGR) of germlings of Scytosiphon ( $\mathrm{n}=20-30$ ) acclimated for one month to $5^{\circ} \mathrm{C}$ or for at least two years to $15^{\circ} \mathrm{C}$ (vertical bars $=95 \%$ confidence intervals). Standard light conditions: $60-80$ photons $\mu \mathrm{mol} \mathrm{m} \mathrm{m}^{-2} \mathrm{~s}^{-1}$ and $16 \mathrm{~h}$ light per day

Six weeks after the experiment had begun, mature plants and the release of zoids were observed. At $5^{\circ} \mathrm{C}$, the occurrence of macrothalli was completed in the first six weeks. Formation of sori and the release of spores took place in the following two weeks. To determine more accurately the release of zoids at higher temperatures, immature mac- 
rothalli were incubated at $22,23,24$ and $25^{\circ} \mathrm{C}\left( \pm 0.2^{\circ} \mathrm{C}\right)$. After 4 weeks, there was an extensive release of reproductive cells at $22^{\circ} \mathrm{C}$, a decreased one at $23^{\circ} \mathrm{C}$, and none at $24^{\circ} \mathrm{C}$ or $25^{\circ} \mathrm{C}$. At the last three temperatures, young macrothalli developed from the surface cell layers of the older macrothalli.

The formation of macrothalli was dependent on the experimental temperature, whereas acclimation temperature seemed to be of minor importance. In both experiments, $100 \%$ of the macrothalli were formed after 3 to 5 weeks of cultivation time at 5 to $25^{\circ} \mathrm{C}$, but none at $0^{\circ} \mathrm{C}$ (Fig. 2). Zoids derived from thalli that had been pre-incubated at $15^{\circ} \mathrm{C}$ formed less macrothalli at $27^{\circ} \mathrm{C}$, whereas those derived from thalli that had been pre-incubated at $5^{\circ} \mathrm{C}$ were unable to form macrothalli at the same temperature.

No obvious constrictions were observed in macrothalli under the different environmental conditions. The largest macrothalli in aerated $2-1$ culture vessels, at $10^{\circ} \mathrm{C}$, usually measured $6-10 \mathrm{~cm}$. At higher temperatures, the macrothalli were shorter due to rapid maturation.

\section{DISCUSSION}

This study indicates that Scytosiphon lomentaria from Thessaloniki exhibits a rapid type of development. This means that plurispores from upright thalli developed into a multi-celled lumpy prostrate system from which new upright thalli arose a short time afterwards. The prostrate system was strongly affected by temperature. Day-neutral strains with a similarly fast type of differentiation have also been reported (tom Dieck, 1987; Kristiansen et al., 1991).

Germlings of Scytosiphon grew and then formed macrothalli, albeit in low numbers, at $27^{\circ} \mathrm{C}$, when acclimated to $15^{\circ} \mathrm{C}$, but not when acclimated to $5^{\circ} \mathrm{C}$ (Figs $1 \mathrm{~B}, 2$ ). Macrothalli acclimated to 10 or $15^{\circ} \mathrm{C}$ did not display a different growth pattern (Fig. 1A). This is probably in accordance with the stenothermal character of macrothalli, as confirmed by this laboratory study and other field studies (Dethier, 1981). Germlings of Scytosiphon grew better at higher temperatures than the macrothalli (Fig. 1). This growth pattern is similar to that observed in Colpomenia peregrina (Orfanidis, 1993) and in some members of the Desmarestiales (Wiencke \& tom Dieck, 1989). Kristiansen et al. (1991) observed that the prostrate system of a Scytosiphon strain from Denmark became larger in diameter at high temperatures. This may be a side-effect of decreased macrothallus formation at high temperatures.

Scytosiphon lomentaria from Thessaloniki tolerates a wide temperature range, i.e. from $-1{ }^{\circ} \mathrm{C}$ (present study) to $28^{\circ} \mathrm{C}$ (tom Dieck, 1987). This response is in accordance with the wide geographical distribution of the species in the North Atlantic Ocean (Fig. 3). In contrast to Ectocarpus siliculosus, which has developed ecotypes over its distribution range (Bolton, 1983), S. lomentaria has a uniform upper temperature tolerance of 28-29 ${ }^{\circ} \mathrm{C}$ (tom Dieck, 1987). Kristiansen et al. (1991), studying the temperature-dependent growth of two strains of Scytosiphon from Denmark, observed ecotypic variation in the upper growth limit, with one strain growing at temperatures up to $24.4^{\circ} \mathrm{C}$ and the other strain up to $27^{\circ} \mathrm{C}$. These authors assumed that the period of two weeks, during which tom Dieck's (1987) experiments had been performed, was not long enough to reveal different survival limits between strains. The upper temperature tolerance of the strain from Thessaloniki $\left(28^{\circ} \mathrm{C}\right)$, as reported by tom Dieck (1987), was confirmed in the 


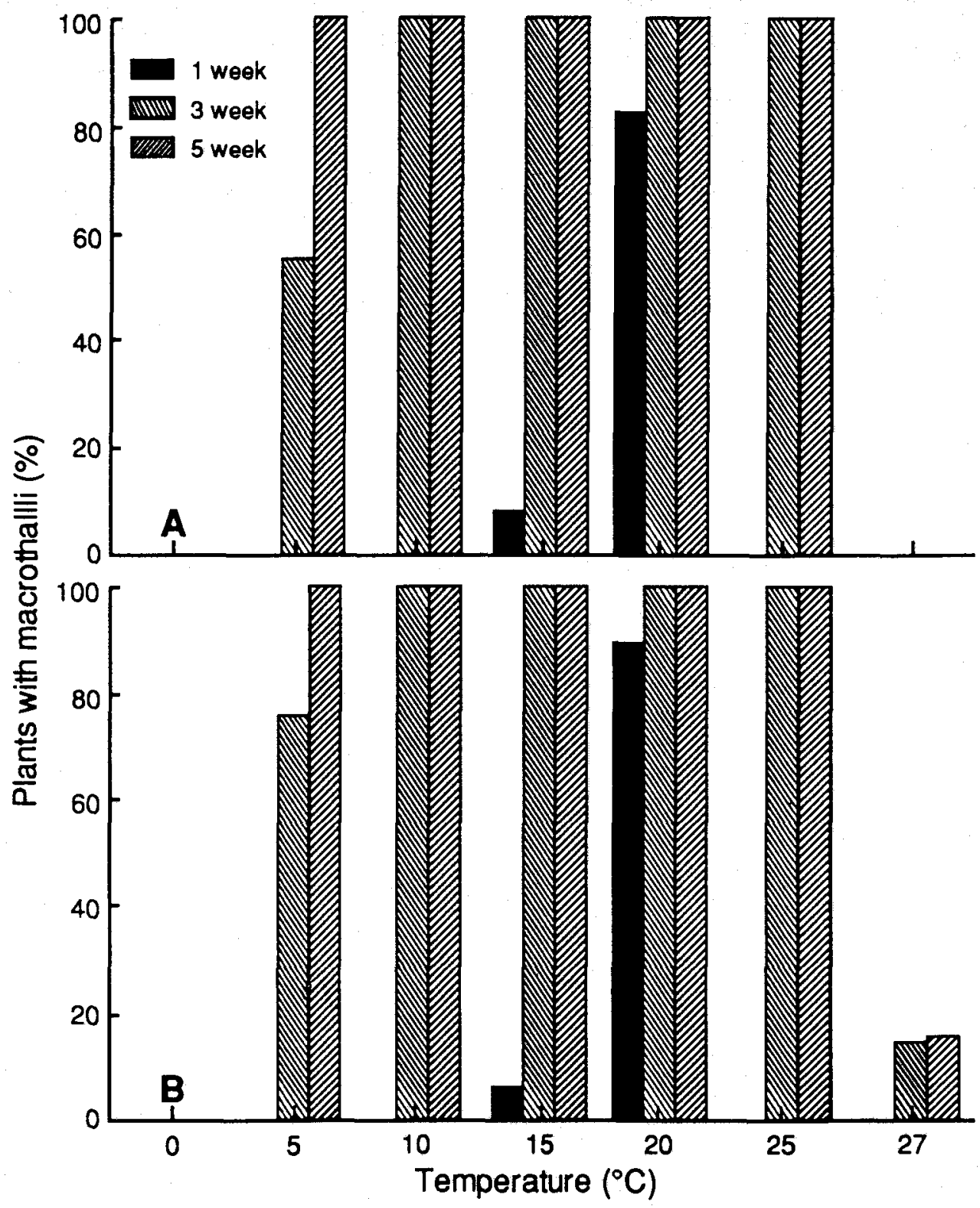

Fig. 2. Temperature-dependent macrothallus formation of Scytosiphon lomentaria ( $\mathrm{n}=200$ ). A: Zoids released from plants acclimated for one month to $5^{\circ} \mathrm{C}$. B: Zoids released from plants acclimated for at least 2 years to $15^{\circ} \mathrm{C}$. Bars indicate percentage of plants with macrothalli after 1,3 and 5 weeks of cultivation. Light conditions: $60-80 \mu \mathrm{mol}$ photons $\mathrm{m}^{-2} \mathrm{~s}^{-1}$ and $16 \mathrm{~h}$ light per day 


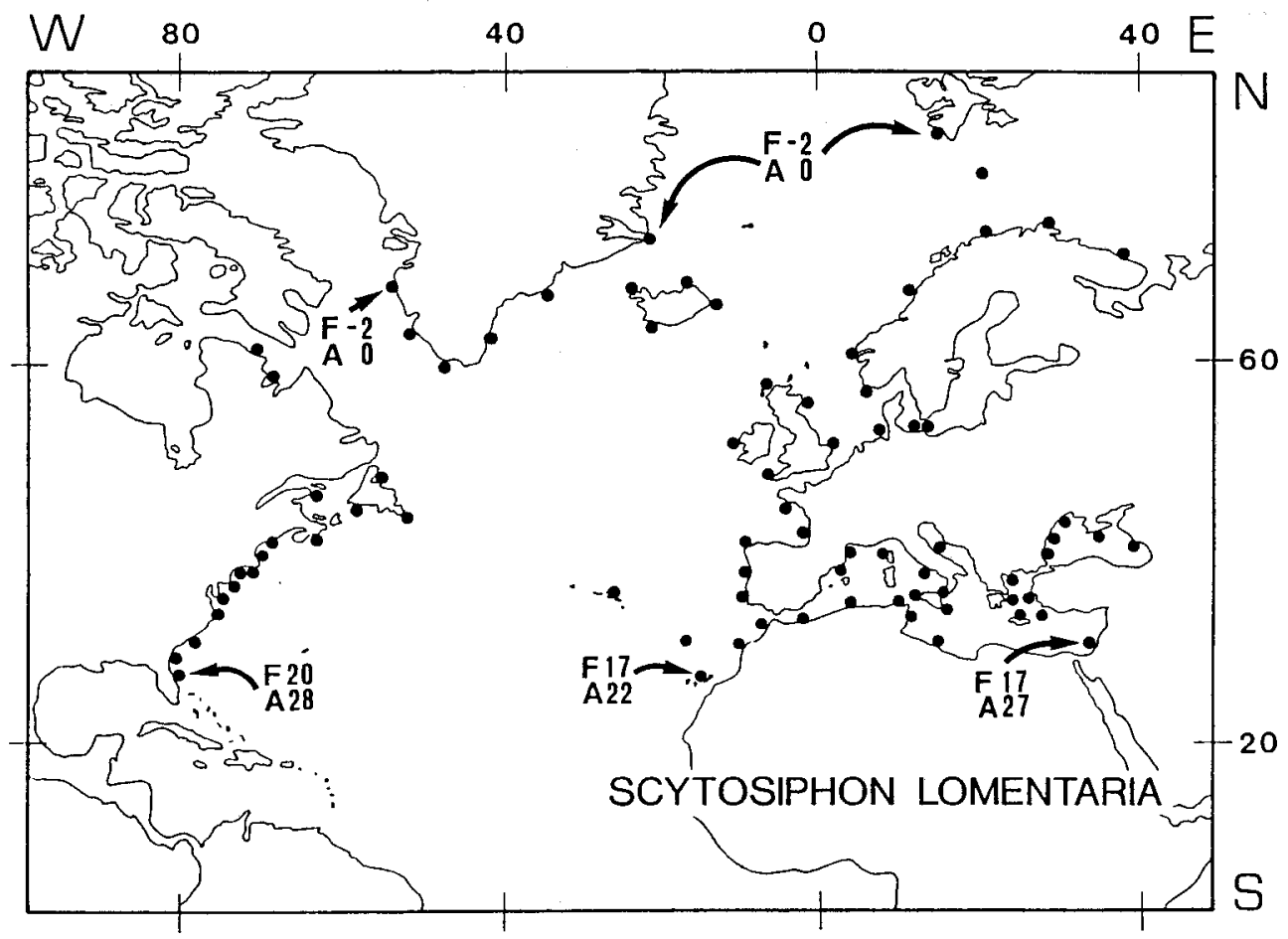

Fig. 3. Distribution of Scytosiphon lomentaria in the North Atlantic Ocean. Map shows the geographic distribution and the ocean isotherms for February $(F)$ and August $(A)$ at the boundaries. The oceanic isotherms were adopted from Gorshkov World Ocean Atlas (1985). Sources: N Atlantic (van den Hoek, 1982; South \& Tittley, 1986), Mediterranean (Furnari, 1984), E Mediterranean (Lipkin, 1972), Aegean Sea (Athanasiadis, 1987)

present study. An exposure time of 2 weeks was found to be long enough to determine the upper temperature tolerance for Polyneura hilliae (Yarish et al., 1987) and the blade phase of Porphyra leucosticta (Orfanidis \& Haritonidis, 1996). However, the upper tolerance limit of Enteromorpha linza was fixed after an exposure time of 6 weeks (Orfanidis \& Haritonidis, 1996), and in filamentous gametophytes of Laminaria spp., the upper tolerance limit was not fixed, even after 8 weeks of incubation (tom Dieck, 1993).

The response to low temperatures of Scytosiphon lomentaria from Thessaloniki, which survived but did not grow or reproduce at $0^{\circ} \mathrm{C}$, cannot explain the northern distribution boundary of this species in the North Atlantic Ocean (Fig. 3). According to van den Hoek (1982), the northern distribution boundary of this species could be a growth and/or reproduction boundary at the $0^{\circ} \mathrm{C}$ August isotherm. This corresponds with a lower mean summer temperature of $0^{\circ} \mathrm{C}$, allowing growth and reproduction of Arctic populations. This boundary is also insufficiently explained by the low temperature requirements of one eastern Canadian strain of Scytosiphon. This strain grew and formed macrothalli, but did not reproduce at $0^{\circ} \mathrm{C}$ (Correa et al., 1986). The lower reproduction limit of Scytosiphon from Thessaloniki and that of more northern strains of the species (Correa et al., 1986; Pedersen et al., 1987; Kristiansen et al., 1991) seems to be at $5^{\circ} \mathrm{C}$. 
One explanation would be the existence of an Arctic ecotype. Temperature ecotypes of Scytosiphon with respect to morphogenesis, growth and reproduction have been reported by Lüning (1980), tom Dieck (1987) and Kristiansen et al. (1991). Another explanation could be related to the habitat. Scytosiphon lomentaria is found in the eulittoral and upper sublittoral zones and is often exposed to air temperatures which may differ remarkably from seawater temperatures. This could influence its reproductive behaviour as well as its northern geographical distribution. High air temperatures were shown to promote sporogenesis in the Trailliella phase of the red alga Bonnemaisonia hamifera, even when seawater temperatures were lower than the lowest temperature required for reproduction (Breeman \& Guiry, 1989).

The response of Scytosiphon lomentaria from Thessaloniki to high temperatures (Figs 1,2) and the existence of this species in the eastern Mediterranean (Fig. 3) suggest that the southern distribution boundary of this species along the coast of the eastern Atlantic Ocean is a growth boundary at the $17^{\circ} \mathrm{C}$ February isotherm. This isotherm corresponds with an upper mean winter temperature of $19^{\circ} \mathrm{C}$ that allows sufficient growth of the macrothallus. Based on the experimental results of a Scytosiphon strain from Rovinj, Croatia (Lüning, 1980, 1981b), van den Hoek (1982) suggested a southern boundary set by the capacity to form macrothalli at the $17^{\circ} \mathrm{C}$ February isotherm. This corresponds with an upper mean winter temperature of $19^{\circ} \mathrm{C}$. The data for the Scytosiphon strain from Thessaloniki do not allow such an interpretation, as this strain reproduces at temperatures up to $23^{\circ} \mathrm{C}$ and forms macrothalli up to $25^{\circ} \mathrm{C}$ (Fig. 2). This means that the southern distribution boundary of the species would approach the $21^{\circ} \mathrm{C}$ February isotherm, which lies beyond the actual distribution range. Furthermore, the temperature requirements for macrothallus formation are variable. They differ between strains coming from nearby regions or regions of similar geographic latitude. Kristiansen et al. (1991) observed that formation of macrothalli in two different strains from Denmark took place from $7.3-24.4^{\circ} \mathrm{C}$ and $5.1-18.6^{\circ} \mathrm{C}$. Macrothallus formation of an Icelandic strain $\left(66^{\circ} \mathrm{N}\right.$ ) is inhibited at $15^{\circ} \mathrm{C}$ (Lüning, 1980), but that of a strain from western Greenland $\left(69^{\circ} \mathrm{N}\right)$ is not inhibited at that temperature (Pedersen, 1980). Complanate plants from western Greenland were observed to form macrothalli at $20.9^{\circ} \mathrm{C}$ (Pedersen et al., 1987). Strains from East Canada, Nova Scotia/Halifax, also show such local variability (Lüning, 1980; Correa et al., 1986). The highest temperature allowing formation of macrothalli in most of the above strains is of no ecological importance (Lüning, 1981a), as the average seawater temperature in these areas does not exceed $10^{\circ} \mathrm{C}$. Scytosiphon lomentaria has a composite southern boundary in the North Atlantic Ocean, with a lethal boundary at the $28^{\circ} \mathrm{C}$ August isotherm on the east coasts of North America and a growth boundary in the eastern Atlantic. Such composite boundaries have also been observed in several other temperate species (Breeman, 1988).

Acknowledgements. This work was supported by the German Academic Exchange Service (DAAD) and is based on a Ph. D. study in the Department of Biology, University of Thessaloniki. One of the authors (S. O.) is very grateful to Prof. Dr. K. Lüning for his advice and for his hospitality, and also for the working facilities provided by the Biologische Anstalt Helgoland. Thanks are further due to Dr. I. tom Dieck and Dr. A. M. Breeman for their critical review of an earlier draft. We thank A. KiratzidouDimopoulou for assisting in the preparation of the text in the English language. 


\section{LITERATURE CITED}

Athanasiadis, A., 1987. A survey of the seaweeds of the Aegean Sea with taxonomic studies on species of the tribe Antithamnieae (Rhodophyta). Ph. D. Thesis, Goterna, Kungälv, 174 pp.

Berry, J. A. \& Björkman, O., 1980. Photosynthetic response and adaptation to temperature in higher plants. - Rev. Pl. Physiol. 31, 491-543.

Bischoff, B. \& Wiencke, C., 1993. Temperature requirements for growth and survival of macroalgae from Disko Island (Greenland). - Helgoländer Meeresunters. 47, 167-191.

Bolton, J. J., 1983. Ecoclinal variation in Ectocarpus siliculosus (Phaeophyta) with respect to temperature growth optima and survival limits. - Mar. Biol. 73, 131-138.

Breeman, A. M., 1988. Relative importance of temperature and other factors in determining geographic boundaries of seaweeds: experimental and phenological evidence. - Helgoländer Meeresunters. 42, 199-241.

Breeman, A. M. \& Guiry, M. D., 1989. Tidal influences on the photoperiodic induction of tetrasporogenesis in Bonnemaisonia hamifera (Rhodophyta). - Mar. Biol. 105, 5-14.

Correa, J., Novaczek, I. \& McLachlan, J., 1986. Effect of temperature and daylength on morphogenesis of Scytosiphon lomentaria (Scytosiphonales, Phaeophyta) from eastern Canada. Phycologia, 25, 469-475.

Dethier, M. N., 1981. Heteromorphic algal life histories: The seasonal pattern and response to herbivory of the brown crust, Ralfsia californica. - Oecologia 46, 333-339.

Dieck, I. tom, 1987. Temperature tolerance and daylength effects in isolates of Scytosiphon lomentaria (Phaeophyceae) of the North Atlantic and Pacific Ocean. - Helgoländer Meeresunters. 41, $307-321$.

Dieck, I. tom, 1993. Temperature tolerance and survival in darkness of kelp gametophytes (Laminariales, Phaeophyta): ecological and biogeographical implications. - Mar. Ecol. Prog. Ser. $100,253-264$.

Feldmann, N. L. \& Lutova, M. I., 1963. Variations de la thermostabilité cellulaire des algues en fonctions des changements de la température du milieu. - Cah. Biol. mar. 4, 435-458.

Furnari, G., 1984. The benthic marine algae of southern Italy. Floristic and geobotanic considerations. - Webbia, 38, 349-369.

Gorshkov, S. G. (Ed.), 1985. World Ocean Atlas. 2: Atlantic and Indian Oceans. Pergamon Press, Oxford.

Hoek, C. van den, 1982. The distribution of benthic marine algae in relation to the temperature regulation of their life histories. - Biol. J. Linn. Soc. 18, 81-144.

Kristiansen, A. \& Pedersen, P. M., 1979. Studies on life history and seasonal variation of Scytosiphon lomentaria (Fucophyceae, Scytosiphonales) in Denmark. - Bot. Tidsskr. 74, 31-56.

Kristiansen, A., Pedersen, P. M. \& Moseholm L., 1991. Growth and reproduction of Scytosiphon lomentaria (Fucophyceae) in relation to temperature in two populations from Denmark. - Nord. J. Bot. 11, 375-383.

Lipkin, Y., 1972. Marine algal and sea-grass flora of the Suez Canal. The significance of this flora to the understanding of the recent migration through the Canal. - Israel J. Zool. 21, 405-446.

Lüning, K, 1980. Control of algal life-history by daylength and temperature. In: The Shore Environment. Ed. by J. H. Price, D. E. G. Irvine \& W. F. Farnham. Acad. Press. London, 2, 915-945.

Lüning, K., 1981a. Photomorphogenesis of reproduction in marine macroalgae. - Ber. dt. bot. Ges. $94,410-417$.

Lüning, K., 1981b. Light. In: The biology of seaweeds. Ed. by C. S. Lobban \& M. J. Wynne. Blackwell, Oxford, 326-355.

Lüning, K., 1990. Seaweeds: their environment, biogeography and ecophysiology. Wiley, New York, $527 \mathrm{pp}$

Lutova, M. I. \& Feldmann, N. L., 1960. A study of the ability of temperature adaptation in some marine algae. - Tsitologiya 2,699-709.

Orfanidis, S., 1991. Temperature responses and distribution of macroalgae belonging to the warmtemperate Mediterranean Atlantic distribution group. - Botanica mar. 34, 541-552.

Orfanidis, S., 1992. Light requirements for growth of six shade-acclimated Mediterranean macroalgae. - Mar. Biol. 112, 511-515. 
Orfanidis, S., 1993. Temperature responses and distribution of several Mediterranean macroalgae belonging to different distribution groups. - Botanica mar. 36, 359-370.

Orfanidis, S. \& Haritonidis, S., 1996. Effect of acclimation temperature on temperature responses of Porphyra leucosticta and Enteromorpha linza from the Gulf of Thessaloniki, Greece. - Helgoländer Meeresunters. 50, 1-13.

Pedersen, P. M., 1980. Culture studies on complanate and cylindrical Scytosiphon (Fucophyceae, Scytosiphonales) from Greenland. - Br. phycol. J. 15, 391-398.

Pedersen, P. M., 1981. Phaeophyta: life histories. In: The biology of seaweeds. Ed. by C. S. Lobban \& M. J. Wynne. Blackwell, Oxford, 194-217.

Pedersen, P. M., Kristiansen, A. \& Moseholm, L., 1987. The effect of temperature on growth and reproduction of Scytosiphon complanatus (Fucophyceae) from Greenland. - Nord. J. Bot. 7, 729-733.

Precht, H., Christophersen, J., Hensel, H. \& Larcher, W., 1973. Temperature and life. Springer, Berlin, $779 \mathrm{pp}$.

Schwenke, H., 1959. Untersuchungen zur Temperaturresistenz mariner Algen der westlichen Ostsee. I: Das Resistenzverhalten von Tiefenrotalgen bei ökologischen und nicht-ökologischen Temperaturen. - Kieler Meeresforsch. 15, 34-50.

South, G. R. \& Tittley, I., 1986. A checklist and distributional index of the benthic marine algae of the North Atlantic Ocean. British Museum (Natural History), London, 76 pp.

Wiencke, C. \& tom Dieck, I., 1989. Temperature requirements for growth and temperature tolerance of macroalgae endemic to the Antarctic region. - Mar. Ecol. Prog. Ser. 54, 189-197.

Yarish, C., Kirkman, H. \& Lüning, K., 1987. Lethal exposure times and preconditioning to upper temperature limits of some temperate North Atlantic red algae. - Helgoländer Meeresunters. 41, $323-327$ 